\title{
PROBLEMS IN CONTRIBUTORY NEGLIGENCE
}

\section{Thomas M. Cooley, II $\dagger$}

Few lawyers find practical value in analyses of the rationale of negligence or its branches; and in a sense this attitude of disinterest is justified. The many and difficult essays upon negligence and its complement, legal cause, can seldom be of more assistance in the winning of a given litigation than the wordy searches for philosophical absolutes in which the schoolmen are supposed to have reveled.

Nevertheless, in the lifetime of many lawyers practicing today pressures arising within the judicial process have wrought considerable, if unacknowledged, alterations in the operation of certain aspects of the common law negligence doctrine. Outside pressure has removed from its sphere of operation certain problems typical of those which are usually assigned to it for solution by practitioners and commentators alike. And it is quite possible that there is a trend in this latter direction which has not yet reached its fullest development. For example: It is assumed without statistical research that the two greatest sources of accidents which would ordinarily give rise to typical negligence litigation are the industrial process and the automobile. Workmen's Compensation and Employers' Liability Acts have now created a system of compensating the injured party in accidents arising from the first source which would appear almost wholly foreign to the jurists who gave us the negligence doctrines we still use. ${ }^{1}$ Already there are proposals that automobile accidents be similarly removed from the operation of negligence law ${ }^{2}$ even as it now stands, expanded and distorted by the incorporation of multitudes of criminal statutes aimed at diminishing the dangers of automobile operation. ${ }^{3}$ The arguments

† A. B., 1932, University of Michigan; LL. B., 1935, Harvard University; Instructor in Law, Western Reserve University Law School; author, What Constitutes a Gift to $a$ Class (1936) 49 HARV. L. REv.; contributor to various other legal periodicals.

I. See generally as to the extent and nature of the deviation from common law rules entailed in Workmen's Compensation Laws, Bohlen, A Problem in the Drafting of Workmen's Compensation Acts (I9I2) 25 HARV. L. REv. 328; HARPER, TORTS (I933) $\$ \$ 207-215$; and for a brief statement of the effect of federal employers' liability legislation, see Mole and Wilson, $A$ Study of Comparative Negligence (1932) I7 CoRN. L. Q. 333, 359-363. See also, Smith, Sequel to Workmen's Compensation Acts (IgI4) 27 HARv, L. REv. 235.

2. Report of the Committee to Study Compensation for Automobile Accidents to the Columbia Research Committee for Research in the Social Sciences (1932) 138143. See, for a brief summary of the recommended plan, $A$ Note on the Automobile Accident Compensation Plan (I936) 3 LAw \& ConTEMP. PROB. 579; cf. Van Buren Perry, The Undue Process of Law (1937) 2I J. Axr. Jud. Soc. 74, 75.

3. For an analysis of the impact of criminal statutes upon civil actions see Lowndes, Civil Liability Created by Criminal Legislation (1932) 16 MINN. L. Rev. 361 ; cf. Morris, The Relation of Criminal Statutes to Tort Liability (1933) 46 HaRv. L. REv. 453. 
of the proponents of this change are extremely difficult to answer, ${ }^{4}$ and, if the practical problems of economics and administration can be solved satisfactorily, ${ }^{5}$ it seems possible that we shall ultimately see negligence litigation cut off in large part from its second great source. ${ }^{6}$

Thus, in the two fields where negligence litigation has had its most thorough testing and, perhaps, its widest development, it is either largely superseded or subject to strenuous attack as a method of disposing of the problems with which it is generally assumed to deal.

The practical significance of these changes wrought from without the judicial system should require no emphasis. But they are ordinarily treated as having no connection with the rationale of negligence. The traditional view of its functions remains unchanged, and such developments are regarded as legislative exceptions which are interesting enough in themselves, perhaps, but which necessitate no revision of attitude towards the main problem. This is too comfortable a view. These developments show, at the minimum, that the function attributed to negligence litigation in traditional statements of its rationale is broader than the facts of its operation now warrant. The purpose of this paper is to outline a somewhat less ambitious rationale which seems better fitted to the function the negligence doctrine now properly fulfills and to examine some of its internal complexities from the viewpoint so determined. For reasons which will appear during the discussion, this examination of the growing alterations and complications within the judicial process will concern itself largely with contributory negligence and some of its attendant doctrines. The practical utility of such an analysis is that, if successful, it may not only promote clearer understanding of what now exists, but also serve as a basis for avoiding further unnecessary complications in and, possibly, ill-

4. There appears to be little disagreement as to the existing evils, for a study of which see Report of Committee, note 2 supra. See also Corstvet, The Uncompensated Accident and Its Consequences (1936) 3 LAW \& Contenr. ProB. 466; Lewis, The Merits of the Automobile Compensation Plan (1936) 3 LAw \& ConTEMP. PRoB. 583; Smith, Lilly and Dowling, Compensation for Automobile Accidents, a Symposium (1932) 32 CoL. L. REV. 785, 803, 813. Compare, on the practical operation of the plan suggested, Sherman, Comments on Report by the Committee to Study Compensation for Automobile Accidents (Ass'n of Casualty and Surety Executives, N. Y. 1932).

5. There is at least serious doubt about this. For criticism and variant suggestions, see Lilly, A Brief Statement of Certain Points in Opposition to Compulsory Compensation Insurance for Motor Vehicle Accidents (1930) I6 A. B. A. J. 756; Meivin, Compulsory Compensation Automobile Insurance (I934) 6 N. Y. STATE BAR Ass'N BuLt. 268. On this point, experience with the Massachusetts Compulsory Insurance system [Mass. Laws 1925, c. 346, 3 MAss. ANN. LAws (1933) c. 90, $\$ 34$ (a)34 (j)] has been widely discussed. See, generally, Blanchard, Compulsory Motor Vehicle Liability Insurance in Massachusetts (1936) 3 LAW \& ConTEMP. ProB. 537.

6. Inroads upon the operation of the common law doctrines are, of course, represented by such statutory provisions as the Massachusetts Compulsory Insurance Act, note 5 supra; financial responsibility laws, as to which see generally, Braun, The Financial Responsibility Law (I936) 3 LAw \& ConTEMr. ProB. 505; guest acts, and all criminal statutes applicable in civil litigation. But since these are purportedly assimilated into negligence law as it now stands or are considered irrelevant to its function, they are not important to the present argument. 
considered legislative and other attacks upon the negligence concept in the field within which it properly operates.

\section{I}

The traditional rationale of negligence, worked out largely by scholars, has had widespread appeal to courts and lawyers as well. The notion that substantially all the problems arising from accidental injuries may be solved by reference to a single and apparently easily comprehended legal formula is an attractive one. When able scholars find doctrinal foundation for such a formula in absolutes of social policy which preclude the possibility of altering its basic tenets, no ordinary difficulties in its practical application are likely to disturb the complacency with which the profession regards it. Thus, Professor Bohlen's classic essay on contributory negligence ${ }^{7}$ makes any other doctrine unthinkable. To require one man to take better care of others than such others are bound to take of themselves, ${ }^{8}$ he states,

“. . . would be to unduly burden business and enterprise, to make of those engaged therein the guardians of those apt to be affected by their operation, and at the same time to rob of selfreliance, and so enervate and emasculate and in effect pauperize the latter by accustoming them to look to others for protection and by removing from them all responsibility for their own safety." 8

Similar reasoning has supported the negligence doctrine itself. ${ }^{10}$ And the spectre of socialism has not infrequently appeared when alternatives were envisaged.11

There are two immediate objections to this type of approach to the problems of common law negligence litigation. The first is that

7. Bohlen, Contributory Negligence, Setected EsSAYs ON THE LAW OF TORTS (1924) 469. Cf. Davis v. Guarnieri, 45 Ohio St. 470, I5 N. E. 350 (1887).

8. This is not a necessary result of the elimination of contributory negligence. The effect of the application of comparative negligence might be described as the imposition of a duty on the defendant to take at least as good care of the plaintiff as he takes of himself. Such verbal niceties are not, however, of prime importance here for reasons to be discussed at length below.

9. Bohlen, note 7 supra at 490-491. Cf. Schofield, Davies v. Mann: Theory of Contributory Negligence, SELECTED ESSAys ON THE LAw OF TORTS (I924) 543, 549. Cf. Pound, The Economic Interpretation and the Law of Torts (I940) 53 HARv. L. REv. 365 .

ro. See Green, Junge ANd JuRx (1930) 65-74, and authorities cited; Cowan, The Victim of the Law of Torts (I939) 33 ILL. L. REv. 532 passim.

Ir. "With a mechanistic philosphy as to human motives and a socialistic viewpoint as to the function of the state, we may return to the original restult of liability for all injurious conduct, or conceivably have an absence of liability for any conduct, with the burden of loss shifted either to groups of persons or to the entire community." Seavey, Negligence-Subjective or Objective? (I927) $4 \mathrm{I}$ HARv. L. Rev. $r, 28$. No criticism is intended of this survey or of the conclusion reached. But it is submitted that the relative "socialism" of the alternatives is irrelevant to their accurate analysis. 
there is at least grave doubt whether the outcome of isolated litigations between individuals or groups has or ever had the assumed effects upon the economic and ethical behaviour of the populace as a whole. ${ }^{12}$ The second and far more serious objection is that, even assuming the achievement of some effects upon community behaviour by either the symbolic punishment of those whose conduct is thought to be substandard or by indemnifying their victims, ${ }^{13}$ the courts, operating only upon isolated adversary situations, are in no position to exercise a sound and informed judgment upon public policy issues of this magnitude and scope. A dispute between $A$ and $B$ as to who is the more properly to be held responsible for an accident is not the ideal setting for contemplation of the merits and demerits of opposed views as to the social consequences of accidents of that particular type and the policies to be adopted in dealing with them on a large scale. No matter how widespread the effects of great numbers of similar accidents may be or how many diverse interests may be concerned, the court must view each one as the source of controversy between $A$ and $B$ alone, permitting consideration of all other affected interests to enter in, if at all, solely as a function of something akin to judicial notice or judicial predilection for certain social and economic views. ${ }^{14}$ Direct repre-

12. This doubt is widely shared by commentators. See Leflar, Contribution and Indemnity Between Tortfeasors (1932) 81 U. OF PA. L. REv. I30, 132-I39; Lowndes, Contributory Negligence (1934) 22 GEo. L. J. 674, 682; Mole and Wilson, note I supra at $644-645$.

13. That the element of punishment enters into the ordinary tort case seems clear. This is generally admitted in the cases where defendant's conduct has been wilful. See Bohlen, note 7 supra at 49I-492. But it is difficult to agree that those cases mark the limits of the area in which retribution for social wrong is partially determinative of the tort rules. Contrast the statement, "The modern tort recognizing and enforcing social duties is in all its features purely compensatory." Ibid. In the first place, while negligence law does not permit purely punitive damages as such, juries probably vary the amounts awarded for similar injuries in direct proportion to the stimulus afforded their retributive feelings by the conduct of the defendant. Certainly all plaintiffs' lawyers shape their arguments upon this supposition. And the limits of appellate review are broad enough to permit this factor to have a considerable effect in the outcome. Moreover, the very fact that social policy is so often cited as a determining factor in the formulation of negligence rules is an admission of the same tendency on the part of judges. Whenever $A$ is made to pay money because what he has done violates some social policy, that payment can no longer properly be said to be "purely" compensatory, even if he pays it in an amount determined by the extent of $B^{\prime} s$ injury and pays it to $B$. To be sure, $B$ gets no additional money because of $A$ 's badness. But $A$ pays in part because of his social transgression. The very prevalence of the words "fault", "blame" and "wrong" in judicial and other discussions of negligence law likewise indicate something other than a simple compensatory system. And legal cause itself is clearly a method of limiting defendant's duty of compensation in accordance with considerations some of which are irrelevant either to the extent of plaintiff's injury or defendant's factual participation in its occurrence. See generally, Cowan, note ro supra. $C f$. Isaacs, Fault and Liability (I9I8) 3I HaRv. L. REv. 954.

As to the extent to which isolated litigations may be supposed to affect society generally see Robinson, LAW AND the LaWyers (I935), and ARNold, Symbols or GOVERNMIENT (I935).

I4. See Holmes, The Common Law (I88I) 35-36. In the field of constitutional law, the importation of the economic and social predilections of the judges into the terms of the fundamental charter has long been the subject of heated debate. See Mr. Justice Holmes dissenting in Lochner v. New York, 198 U. S. 45, 75 (1905) 
sentation of any interests other than those of the immediate participants is precluded by the very form and purpose of the inquiry and would be inappropriate in any event since the broader effects of given types of accident are not usually determinable from any single instance. If it is true, as the proponents of remedial legislation contend, that uncompensated injuries resulting from automobile operation are the source of serious burdens upon the community which could be avoided by some sort of community action,,$^{15}$ a tort case is not the place either to discover that fact or to seek remedies for it. ${ }^{16}$ In short, wherever the assumptions of the individualist philosophy implicit-and explicit-in negligence cases are challenged, it becomes impossible for the courts to decide the resulting policy issue with the requisite facilities for informed judgment.

It will be observed that the above argument applies to all negligence cases, although only those which occur in large numbers and possess certain common characteristics are used for illustration. It is true that the courts lack facilities for the informed determination of explicit social policy with respect to such problems as that presented in Browm v. Kendall ${ }^{17}$ quite as much as they do with respect to those occurring in the cases now governed largely by workmen's compensation laws. Nevertheless, social thought has not yet reached the point

and compare the view of the present court in Osborn v. Ozlin, 3Io U. S. 53, 62 (I939); Coleman v, Miller, 307 U. S. 433, 453-454 (I938). It is less generally recognized that the process by which such views are incorporated into the generalities of common law doctrine is precisely the same as that by which the broader generalizations of the constitution are made to express them. The effects are, of course, different. Constitutional interpretation may preclude legislative change, while rigidification of common law doctrine may simply invite it. The distinction between the gradual development of standards, to which Holmes refers as a proper legislative function of the judiciary, must be carefully distinguished from the explicit importation of rigid social philosophies, which he denounces.

15. See authorities cited in notes 2 and 4 supra. The premise, of course, is one which an extreme individualistic philosophy denies altogether.

I6. The only judicial alternative to some sort of distribution of loss based on fault would seem to be imposition of absolute liability. In general, however, that is an unsatisfactory solution. It partially achieves the same result as legislation which shifts the burden of loss to some selected group. But the method of selection is haphazard in the extreme. Furthermore, the courts lack power to make certain that the loss will be spread among the group by insurance or some similar device. They also lack facilities for discovering whether, even assuming that all prospective defendants will insure, the economic burden will be excessive. Accordingly, when absolute liability is imposed by common law there is a strong possibility that economic difficulties will ensue, that some defendants will not insure and, in consequence, some of them may be pauperized while some plaintiffs will go without the compensation the rule was intended to give. Finally, not only may the imposition of absolute liability thus fall substantially short of its object and even be positively harmful, but it runs the risk of meeting hostile popular reaction. Careful legislative action, on the other hand, may avoid all of these difficulties; and it therefore seems preferable in any case where distribution of loss on some basis of fault has become inadequate.

Note, however, the conclusion that there is a steady erosion of fault as the sole ground for shifting loss to the defendant in automobile cases. Nixon, Changing Rules of Liability in Automobile Accident Litigation (1936) 3 LAW \& Contexp. Proв. 476.

17. 60 Mass. 292 ( 1850$)$. 
where the more isolated types of accident are regarded as presenting any social problem of general significance, and no machinery has yet been suggested for taking care of them by any means other than the typical adversary legal proceeding. ${ }^{18}$ Accordingly, we may expect that the great mass of such problems will continue to be handled by the familiar legal techniques. Where the size and common characteristics of the problems raised by a given type of accident have not yet made it a subject of active and direct community concern, there is as yet nothing to create an articulate conflict of social policies with respect to the method of disposing of it.

In such cases the only policy which really demands attention is that which requires the solution of individual controversies according to some generally acceptable system of rules. The search for absolutes of social philosophy is irrelevant. Of course, the "instinctive preferences and inarticulate convictions" 18 of judges and their views of "what is expedient for the community concerned" 20 will and should guide them in the task of developing rules which comport with the general ideas of fairness of the community in which they sit. To the extent that the rules do prove acceptable, they will prevent other methods of solution less orderly than the use of legal processes from being condoned. But to make these instinctive preferences, convictions and views explicit and to identify them with rigid philosophical systems is to risk the possibility that they will fail of their purpose. ${ }^{21}$ Communities have a way of changing faster than their stated philosophies admit.

If the pretensions of the law of negligence had been consciously limited to the function thus marked out by the very nature of the adversary system of litigation of which it is a part, many of its more difficult problems might have been avoided. There are abundant signs within the judicial process that the rules worked out by courts and writers who have approached ad hoc situations with their eyes firmly

I8. It is quite possible, as Professor Seavey suggests in the excerpt quoted note II supra, that changes in social viewpoint may ultimately result in shifting losses from all accidental injuries to selected groups or to the state. It is enough for present purposes to say that currently there is no demand for such a solution for the great mass of isolated tort litigations, although state care of paupers may be viewed as achieving a partial approach to the latter result in certain extreme cases.

I9. Holmes, op. cit. supra note I4 at 36 .

20. $I d$. at 35 .

2I. This argument does not deny the validity of the view that standards of conduct must be of general applicability and capable of general understanding. Id. at Iro-III. Some of the less restrained modern criticisms of the operation of the Anglo-American legal system-see e. g. Frank, LAw AND THE Modern MIND (1930); RODELL, WOE UNTO YOU LAWYERS! (I939), seem to suggest that all generalized legal rules are wrong in and of themselves; but it seems apparent that, whatever their demerits as viewed from a perfectionist standpoint, they reflect a very real demand on the part of those to whom they apply. It is difficult to believe that there would be popular acceptance of a legal system in which each case was treated as unique and decided without reference to any generally applicable formula. 
fixed on philosophical abstractions are not working well, even as applied to the problems whose characteristics do not bring them forcibly to public attention. To predict that this situation will produce popular revolt would be, of course, to fall into the error implicit in views already criticized. The populace is not so sensitive to the workings of the judicial process. But the judicial process itself may be. Judges and juries react to unfair results in individual cases, and their struggles to avoid such results will inevitably confound confusion the more if accompanied by a sincere belief that the doctrines responsible for the difficulty are indispensable to the maintenance of our whole social order. And eventually, growing confusion in the workings of tort law might lead to the necessity of reform from without.

The indications that present rules are not working well even within the field of relatively isolated types of accident are numerous. They comprise scholarly dissections of the theory of negligence itself, covert judicial attacks upon certain aspects of its operation such as that implicit in the development of the last clear chance doctrine, and direct legislative onslaughts and revolts on the part of juries in what is probably a significant number of cases.

Although these evidences might be otherwise construed, it is believed they point to no fundamental defect in the negligence concept itself. The idea that a deviation from ordinary prudence is a prerequisite for shifting to the actor the loss resulting to another from his conduct seems generally satisfactory for the purposes it properly serves.

The question has been raised by its critics why one should be permitted to injure his neighbor without being forced to bear the resulting loss merely because the injury results from a course of conduct regarded as prudent. ${ }^{22}$ This, to the social philosopher, is an extremely interesting and difficult question. He may well puzzle over why such a situation is generally condoned. It is enough for the judge if he is sure that it is; and there is danger in any attempt on his part to formulate philosophical explanations and incorporate them into legal rules. If his explanations are correct, it is doubtful how much effect they have on popular thinking. ${ }^{23}$ If they are wrong, they may well aid in rigidifying a rule which, while based on accurate observation at the time, subsequently becomes useless or positively harmful to the

22. See Cowan, note Io supra at 54I: "Why should the injured party be forced to absolve a non-negligent individual who has harmed him? Let the state foot the bill if it wants to encourage this kind of right-minded but harmful conduct." It might be added that justification of the accident-preventing function of tort liability. if it actually has any, is also difficult. The fairness of making $A$ pay money to $X$ so that $B$ and $C$ will be more careful in the future, thus benefitting society, seems questionable. $C f$. Schofield note 9 supra at 550 .

23. See note I3 silpra. 
effective solution of the problems to which it is to be applied. The sufficient reason for this basic rule of negligence seems to be that the prevalent popular conceptions of justice and causation are in accord with it. Whether for economic, ethical, or other reasons, activity is generally accepted as the normal state of affairs, and only such types of activity as seem exceptionally and unjustifiably dangerous are thought to require the shifting of loss to the actor when harm results. $^{24}$ No analysis of the underlying psychological or other reasons for this state of mind is either necessary or useful in predicating upon it rules of law the function of which is solution of controversies in a society which entertains it.

A somewhat similar answer may be made to critics of the evident crudity of the standards worked out under the heading of negligence. If the function of the concept is, as suggested, simply to provide a lubricant for the frictions caused by accidents occurring in a highly complex society, it must do so by the application of relatively rough and ready standards. In the first place, the acceptability of the results obtained will be largely determined not by accurate criticism based on scientific grounds, but by a necessarily nebulous popular concept of fairness. ${ }^{25}$ Whether or not the intellect approves this situation, it is dictated by a number of factors which seem unavoidably to lead to it. The human limitations-qualitative and quantitative-on the capacities of judges and juries preclude the detailed scientific analysis of many of the matters which psychologists would consider essential to the determination of "fault" in any situation, even assuming the existence of the term as a valid scientific tool. ${ }^{26}$ Still more does "cause" present scientific and logical questions which baffle the highest types of specialized minds. ${ }^{27}$ Even if judges and juries were or should become competent to handle such matters, the limits of the evidentiary system would either preclude the necessary proof or expand the simplest tort litigations to a point where sheer bulk might shortly bring the entire court system to a halt. Finally, if these substantial hurdles were cleared, it is altogether probable that the resulting adjudications would

24. The legal commentator may, of course, be much interested in this question. Holmes, op. cit. supra note I4 passim; Ames, Law and Morals, SELECTED Essays ON THE LAW of TORTS (1924) I; Cowan, note Io supra at 54I et seq.; Lowndes, note 12 supra at 688 .

25. See for an excellent analysis of the correspondence of the negligence standards to this concept, Seavey, note II supra.

26. Id. n. 2, with which compare RoBINson, op. cit. supra note i3 passim.

27. See Eldredge, Culpable Intervention as Succeeding Cause (I937) 86 U. of PA. L. REv. I2I, I2I-123. Cf. Cowan, note Io supra at 536-539. Of course, the whole problem of legal causation is here involved, but extensive citation of authority on this point would seem a work of supererogation. Reference may be made to the classic essays by Beale, Bohlen, Green, McLaughlin and Jeremiah Smith which are familiar to every student of the subject, and also to a recent article, Morris, On the Teaching of Legal Cause (1939) 39 CoL. L. REv. 1087. Cf. Cowan, The Riddle of the Palsgraf Case (1938) 23 MinN. L. Rev. 46. 
fail to satisfy current popular standards of fairness and thus would be quite likely to fall short of their stated objective. ${ }^{28}$

Accordingly, the amorphosity of the "ordinary prudence" standard, altered somewhat, if not alleviated, by the haphazard acknowledgment of certain more specific factors such as purported expertness in some callings, obvious "physical" handicaps, and the like, ${ }^{28}$ should probably not be too heavily criticized. Neither philosophy nor science can approve it, but it apparently satisfies the instinctive demands of the unscientific and non-philosophical; and that is what it is for.

The real source of dissatisfaction with negligence litigation must be sought elsewhere. If the notion of shifting loss in accident cases to such defendants only as are found to have acted with less than ordinary prudence finds general acceptance, what is responsible for the strains within the process that clearly show on the surface? The answer seems to lie in the response to the rules of contributory negligence as they are now-or purport to be-applied. When any of the published attacks on the doctrine are analyzed or when the foci of confusion surrounding it within the judicial system are studied, the contributory negligence doctrine inevitably appears as a major source of difficulty.

A brief listing and examination of the indicia of discontent with contributory negligence ${ }^{30}$ should suffice to show both the source of difficulty and the nature of the only solution which, in the light of what has been said above concerning the function of negligence law generally, seems promising.

\section{II}

The basic proposition of contributory negligence, that a plaintiff who is negligent in the slightest degree cannot recover from a de-

28. The difficulty which modern penologists and criminologists have met in attempting to change the popular views of criminal justice may be indicative of the likely reaction to such a change in the civil rules. The more so because there seems to be little doubt that moral indignation affects the popular standards of fairness in civil cases as much, probably, as do economic and other social preconceptions. See Lowndes, note 12 supra at 688 . See also note 13 supra.

29. See for general discussion of the nature and scope of the rules by which ordinary prudence is particularized in the attempt to make it reflect some more obvious types of special capacity or incapacity; Seavey, note ro supra.

30. The historical and purely logical problems have been covered elsewhere. Bohlen's thesis that the absence of challenge to contributory negligence when it was first announced indicates its strong historical roots (Bohlen, note 7 supra at $469-470$ ) seems adequately answered by the argument in MacIntyre, The Rationale of Last Clcar Chance (1940) 53 HARv. I. REV. II25, I127-I232 that, at its inception, the doctrine was not thought of as being as stringent as it later became. Similarly, the frailty of the doctrine on logical grounds is covered at length in Lowndes, note 12 supra. See also Cowan, note ro supra. It is intended here simply to show the practical difficulties in application of a doctrine the logical and historical frailties of which are brought sharply to focus by the inherent injustices of its operation. Extensive citation of cases upon all the branches of last clear chance will be found in Note (1934) 92 A. L. R. $47-150$. 
fendant who is guilty of nothing worse than negligence in no matter what degree, now passes without direct judicial challenge. Perhaps the plainest indication of dissatisfaction with it is one which is not subject to exact proof. The tendency of juries to reach compromise verdicts in cases where the defense is invoked to bar a plaintiff whose conduct seems to them less reprehensible than that of the defendant ${ }^{31}$ has been remarked. ${ }^{32}$ Little more can be said other than to point out that to whatever extent the tendency does exist, it marks a failure of the doctrine, pro tanto, to satisfy the popular conceptions of fairness insofar as one can assume that jury verdicts reflect those conceptions. ${ }^{33}$

The doctrine of last clear chance has developed in a manner which plainly suggests a similar reaction on the part of judges. Judicial discontent with the idea that a negligent plaintiff may recover nothing from a defendant whose conduct seems the more tinged with fault ${ }^{34}$ has found expression in a doctrine which presents analytical difficulties characteristic of situations in which settled but distasteful rules are being covertly avoided. Demonstration of this attribute requires a rather detailed examination of the various categories in which the doctrine appears.

The easiest case is the first variety of so-called "conscious last clear chance". Here the plaintiff has negligently exposed himself to injury and has become helpless to prevent it. Subsequently the defendant becomes conscious of the danger and fails to avert injury although capable of doing so. ${ }^{35}$ Liability is imposed upon the defendant because, it is said, piaintiff's negligence is not a proximate cause of the accident, having been isolated by his helplessness and defendant's subsequent negligence. ${ }^{36}$ This is plainly mere assertion. In the first place, all distinctions between causes as proximate and non-proximate are subject to

3I. It is doubtful to what extent this result is reached where the plaintiff appears to be the more responsible for the accident, although still not solely so.

32. Lowndes, note 12 supra at 674 .

33. As to the differing functions of judge and jury with respect to the application of those conceptions, see Eldredge, note 27 sipra at I2I-123. Cf. HolsiEs, op. cit. supra note 14 at $122-124$.

34. See generally MacIntyre, note 30 sipra; Note (I934) 92 A. L. R. 47.

35. These are, of course, the "discovered peril" cases. Cf. Johnson v. Stewart, 62 Ark. I64, 34 S. W. 889 (1896) ; Provo v. Spokane etc. R. R., 87 Ore. 467, I70 Pac. 522 (IgI8). The segregation of these cases from other "conscious last clear chance" situations has now been approved by the Restatement. REsTatenIENT, ToRTs (I934) $\$ 479$.

36. Analogy to reckless or wanton misconduct cases seems inexact. HARPER, TORTS (1933) \& 138. Realization of peril does not normally make an actor's conduct reckless and wanton unless he simply fails to act. If he acts in a sub-standard manner, this ordinarily is regarded as simple negligence just as is failure to realize peril. Clearly the requisite "indifference to consequences" [Atchison T. etc. Ry. v. Baker, $79 \mathrm{Kan} .183,98 \mathrm{Pac} .804$ (1908)] does not invariably exist in this situation, although, of course, it may. Contrast, however, the treatment of last clear chance cases as questions of "gross negligence" in some jurisdictions. See e. g. Denman v. Johnston, 85 Mich. 387,48 N. W. 565 (I89I) ; Cox v. Terminal R. R. Ass'n, 33I Mo. 910, 55 S. W. (2d) 685 (1932). 
suspicion of being simply conclusions which result from inarticulate judgments of practical politics. ${ }^{37}$ Secondly, this particular treatment of causation is at variance with standard practice. It is not ordinarily said that mere inability to avert the consequences of an act, once performed, keeps that act from "causing" injury. Nor is the time factor normally of prime significance. ${ }^{38}$ A sufficient demonstration of this is found in the case where $A$, who had a last clear chance, and $B$, whose negligence is "at rest", collide and injure $C$. There seems to be no doubt that both should be liable to $C,{ }^{39}$ assuming, of course, that plaintiff, $B$, was negligent with respect to $C$ as well as himself. Hence the basis of last clear chance is plainly a comparison of the respective faults of $A$ and $B$ for the purpose of settling their controversy only and is not a doctrine concerned solely with the theoretically external problem of cause.

But there is no apparent need to complain of the result. In most cases, it seems more satisfactory than leaving the plaintiff to bear the loss. ${ }^{40}$ The same may be said of the second variety of conscious last clear chance, where the only difference is that the defendant observes, but does not comprehend the danger of, the plaintiff's plight. In either

37. See Andrews, J. dissenting in Palsgraf v. Long Island R. R., 248 N. Y. 339, 162 N. E. 99 (1928). Again, specific reference to the welter of cases and articles on legal cause will be omitted; but it seems safe to say that nowhere in the doctrine of proximate cause is there any specific criterion to be found which will require the classification of plaintiff's negligence as non-proximate here. The same problem has been the subject of difficulty where a defendant seeks to be discharged of all or part of his liability because of the intervention of some other culpable act between his and the injury. And it has been recognized in such cases that the judgment of relative culpability of the actors is the decisive factor in applying the conclusion as to causation. RESTATEMENT, TORTS (1934) \$\$ 447-449; Eldredge, note 27 supra at 123-124.

38. The time factor itself is not free from suspicion of artificiality. It is, of course, reduced to absurdity in the cases following the so-called "Humanitarian Rule". See Note (1932) 92 A. L. R. 47, I28 et seq. But in the typical cases, if nothing but the acts of the parties were considered, it would frequently appear that continuing inaction on the part of both was the source of the accident. Analysis must then be shifted to the duty issue. Plaintiff's failure to act with care violates his duty to do so at the time when it gets him inextricably in trouble. Defendant's continuous failure to act violates his duty at a later time. This is not because he acted later, but because it is determined that his duty arose later. Thus, the time factor does not concern acts but duties. This is explicit in the "unconscious last clear chance" cases, where action is in fact impossible owing to a failure to fulfill the duty of observation. But the defendant does not have a last clear chance because he has a later duty. $\mathrm{He}$ has a later duty because he has a last clear chance. The circle seems complete. For the final contradiction resulting from this confusion of action and duty, see infra, p. 347.

39. Nashua Iron \& Steel Co. v. Worcester, etc. R. R., 62 N. H. I59 (I882). There is some question whether the extreme confusion surrounding joinder, contribution and indemnity questions between tortfeasors has not made a different doctrine possible in Ohio. Cf. Herron v. Youngstown, 136 Ohio St. 190, $24 \mathrm{~N}$. E. (2d) 708 (1940); Losito v. Kruse, I36 Ohio St. 183, 24 N. E. (2d) 705 (1940); Kneiss v. Armour \& Co., I34 Ohio St. 432, I7 N. E. (2d) 734 (1940); and see Notes on these cases, (I939) I5 OHIo O. 477, and (1940) i7 OHIO O. 37. Cf. Bohlen, note 7 sipra at 479 , n. I and Leflar, note 12 supra at I51-154. But it would seem wholly incongruous with the generally accepted rule as to intervening wrongdoers. See RESTATEMIENT, TORTS (I934) $\$ \$ 447-449$. See also Eldredge, note 27 supra, passim, and conclusions stated at $133^{-1} 35$. Cf. Bohlen, note 7 supra at 494-495. A leading case is Lane v. Atlantic Waterworks Co., III Mass. 136 (I872).

40. The prevalence of railroad-crossing accident cases among those adopting the rule may have something to do with the appeal of the plaintiff's situation. 
case the defendant's relevant conduct seems the more at fault ${ }^{41}$ because the circumstances in which it took place probably contained a more immediate and certain threat of danger than did those in which plaintiff acted. It is purely coincidental that the time element enters here. The defendant is held liable not because he acted later but because he was more at fault. It is quite possible to imagine cases where the later act is the less reprehensible. ${ }^{42}$ The unconscious last clear chance doctrine, as ordinarily applied, ${ }^{43}$ offers little more difficulty. That the defendant did not observe the danger seems to offer no better excuse than does his failure to comprehend what he observed. But, again, it is not the time of his action ${ }^{44}$ but the circumstances which are important.

Two final situations are more troublesome. Suppose the defendant, before the plaintiff's helplessness has set in, has negligently rendered himself incapable of observation, ${ }^{45}$ or of action. ${ }^{46}$ Will he be excused in either case because he became helpless first? Any proper solution of this question would seem to require either an affirmative answer on the ground that the parties are now equal, or an examination of the relative imminence and quality of the danger created by the substandard conduct of each party in the attempt to ascertain the greater fault.

The answer given by the Restatement, ${ }^{47}$ and by a number of courts, ${ }^{48}$ however, is quite different. The defendant who rendered himself incapable of action goes free. The one whose antecedent carelessness precluded observation is liable. This distinction has been justi-

4I. In the latter case, his failure to act is chargeable to stupidity rather than faulty coordination or indifference. But stupidity has always been considered blameworthy under the partially objective standard of negligence. See Seavey, note II supra at 12-13. And if so much can be done, no reason appears for not imputing more or less blame according to the obviousness of the danger with which the defendant is confronted.

42. This seems plainly to be the situation in British Columbia etc. Ry. v. Loach [19I6] I A. C. 7 I9 (P. C. I9I5). The result there obtained might have been reached by characterizing the conduct of the defendant as wanton or reckless, of course, as was done in Banks v. Braman, I88 Mass. 367,74 N. E. 594 (1905) and in the jurisdictions where "gross negligence" is used to describe last clear chance situations. But the requirement of indifference to consequences seems excessive; and, in any event, the refusal to permit the defense of contributory negligence to any higher degree of wrongdoing is scarcely less confused than the last clear chance doctrine itself.

43. See HARPER, Torts (1933) § I38 and Restatement, Torts (I934) §479. An extensive collection of cases may be found in Note (I934) 92 A. L. R. 47, IOI-I28. A leading case is Teakle v. San Pedro L. A. etc. R. R., 32 Utah 276,90 Pac. 402 (Ig07). 44. As already noted, note 38 supra, action or inaction alone is here incapable of being related to time. Only by relating time to the slippery duty issue can this result be achieved under orthodox doctrine.

45. Lloyd v. Albermarle R. R., I18 N. C. IоIо, 24 S. E. 805 (I898); Dent v.

Bellows Falls \& Street Ry., 95 Vt. 523, Ir6 Atl. 83 (I922).

46. British Columbia Elec. Ry. v. Loach, [1916] I A. C. 719 (P. C. 1915).

47. RestateMent, Torts (I934) §479, comment $f$. Cf. Winfield, The Law of ToRT, (I937) 443-446.

48. See notes 45,46 , supra. Compare with the Laach case, Boston \& Me. R. R. v. McDuffey, 79 Fed. 934 (C. C. A. 2d, 1897); Trigg v. Water, Light, etc. Co., 215 Mo. 52I, II 4 S. W. 972 (1908). But $c f$. Labarge v. Pere Marquette R. R., I34 Mich. 139, 95 N. W. 1073 (I903). See generally HARPER, ToRTS (I933) § I39. Cf. WINFIELD, THE LAW OF TORT (I937) 443-446. 
fied on the grounds that in the case where power to act is precluded, there is, in the interim of plaintiff's helplessness, no last clear chance, observed or otherwise. The defendant is unable by the exercise of care during that time to act so as to avoid the injury. On the other hand, the unconscious last clear chance cases demonstrate that there is a duty to observe which arises in the interim. If that duty were fulfilled in the cases where the power to observe is precluded, action to avoid the injury would be possible. Hence defendant, in violation of duty, has failed to utilize a last clear chance. ${ }^{49}$

This distinction seems wholly inadequate. Its only justification lies in the duty issue borrowed from the unconscious clear chance cases. It overlooks the fact that the duty of observation in those cases is possible of fulfilment at the time when it is said to arise. It is an exact parallel to the defendant's duty to act in all other last clear chance cases. The plaintiff's duty to act in each case is excused during the interim of his helplessness because of impossibility, while defendant's is not because his is not impossible during that time. But in this last case for the first time the plaintiff's failure to perform his duty is excused despite the fact that the defendant's duty is equally impossible of fulfillment. The only possible basis for such a distinction is the belief that a duty to observe is somehow more strict than a duty to act. ${ }^{50}$ That is in the last analysis a question of comparative fault. But nothing in the distinction suggests any reason for finding less fault in an antecedent negligence which precludes action with respect to observed helpless plaintiffs than in one which prevents their observation. It is quite possible that, on the facts of the cases in which the problems arise, the fault of the defendant would seem greater than that of the plaintiff in either situation. Sending out vehicles capable of great destruction either without headlights ${ }^{51}$ or without brakes ${ }^{52}$ is a highly dangerous proceeding. But the distinction postulated between observvation and action is not one which appeals to any of the instinctive categories of fairness. ${ }^{53}$

Accordingly, the last clear chance doctrine appears as an effort to inject a comparative fault element into contributory negligence by making the time element the predominant factor in the proximate cause

49. See Harper, Torts (1933) \$ 139. Cf. Lowndes, note i2 stpra at 706-708.

50. To say that there is a duty to observe a last clear chance is simply a circular verbalism. It supposes that ability to act to avoid injury is the sole criterion. It is not. Where observation is absent, ability to act is precluded. Yet, properly, where observation is possible and could revive the ability to act, its absence does not excuse the defendant. If where it is impossible to observe, the duty continues, it is clear that this is a duty which differs from any other imposed on either plaintiff or defendant.

5I. Dent v. Bellows Falls \& St. Ry., 95 Vt. 523, 116 Atl. 83 (1922).

52. British Columbia Elec. Ry. v. Loach, [I9I6] I A. C. 7I9 (P. C. I9I5).

53. ". . . it is doubtful whether it is either good policy or good sense." Lowndes, note 12 supra at 708 . 
issue raised. In most of the cases in which it is used, this device achieves its end in a more or less satisfactory manner. It also achieves a wholly unwarranted amount of complexity and confusion, and in some of the peripheral cases it seems to operate in a plainly irrational way to bring about highly questionable results.

A similar situation exists with respect to the explicit limitations upon the operation of contributory negligence. These may be summed up by the statement that contributory negligence is a defense only to actions based on negligence. ${ }^{54}$ The source of such a rule is probably to be found in a rudimentary recognition of comparative fault. But its operation does not tend uniformly toward that result. One reason it does not is that, as in the case of last clear chance, the fact that comparative fault is forbidden by orthodox doctrine has necessitated the formulation of particularized rules for various aspects of its application which confess no allegiance to that concept.

The most generally approved and easily explained application of the rule is the one which refuses to permit the defense of contributory negligence to that class of injuries which result from conduct characterized as wilfulness, wantonness, recklessness, or, in some jurisdictions, gross negligence. To the argument that this is clearly based on comparative fault, ${ }^{55}$ the orthodox answer is that the faults involved differ not in degree alone, but in kind. ${ }^{56}$ Such a position is difficult to support. The necessary, albeit difficult, avoidance of the subjective element in the ascertainment even of intent means that, in part at least, intentionality and negligence merely mark degrees in an objective standard of conduct. This is, of course, no reason for objecting to demarcation of the degrees and differentiation in their treatment. Indeed, it seems quite probable that the segregation of "intentional" injuries from those to which plaintiff's inadvertence is a defense accords almost exactly with the results which would be obtained by permitting direct comparison of the respective faults of the parties. ${ }^{57}$ Thus this special limitation upon contributory negligence can be said to be no worse than useless and probably not the source of any substantial confusion.

Less innocuous are the terms wanton and reckless. They mark lesser degrees of departure from the standard of conduct, and the treat-

54. Muller v. McKesson, 73 N. Y. I95 (I8I8).

55. See HARPER, TORTS (I933) §§ I50, I5I. Cf. Gibbard v. Cursan, 225 Mich. 31 I , I96 N. W. 398 (I923) where both parties are guilty of reckless conduct.

56. Atchison, T. \& S. F. Ry. v. Baker, 79 Kan. 183, 98 Pac. 804 (1908); Banks v. Braman, I 88 Mass. 367,74 N. E. 594 (I905).

57. The moral indignation which it is the function of the word "intentional" to evoke characteristically has this result. The logical irrelevance of this factor to a purely compensatory scheme is ably stated in Lowndes, note I2 supra at 688. Nevertheless, as is also stated there, it is a firmly established part of the popular feeling of fairness, and attempts to curb its more deeply rooted manifestations are almost certainly foredoomed. 
ment accorded them in refusing to allow the plaintiff's negligence as a defense probably achieves a result not greatly different from that to be expected from an admitted use of comparative fault in the easier cases which approach intentionality. Clarity disappears in the less obvious situations, however. At this point appears the real difficulty which results from rigid classification. Refinement must stop somewhere or breed confusion of its own. Recognition of this fact has been the chief reason for refusal to subdivide negligence itself. Accordingly, the comparison of fault, even under the thin disguise of epithetical categorization, has traditionally been forbidden beyond this point. ${ }^{58}$ The resulting contradictions in judicial analysis and the very mass of litigation which has piled up at the boundary drawn here indicate that it is not a satisfactory one. ${ }^{59}$ The inevitable difficulty of defining a matter of degree in absolute terms will not explain them. That difficulty is present in numerous other situations in the law without producing so

58. This taboo has evoked learned dispute. Coggs v. Bernard, 2 Raym. Ld. 909, 9I Eng. Rep. R. I, 13 (1703) made one of the most striking attempts at further classification. That decision was attributed to a leaning toward Roman Law in WhaRTON, NeGLigENCE (2d ed. I878) $\$ \S 59-63$; cf. New World v. King, I6 How. 469 (U. S. I853); Thosrpson, Negligence (2d ed. IgOI) $\$ 18$ takes issue with the validity of this explanation. And the attempt has been briskiy condemned in subsequent cases. See e. g. Baron Rolfe in Wilson v. Brett, II M. \& W. II3, I52 Eng. Rep. R. 737 (1843); HARPER, TORTS (I933) \$74 and authorities cited.

59. Adequate compilation and analysis of the cases upon this point would require a sizeable volume. Two full pages of citation in Corpus $J u r i s$ are devoted to cases in which may be found every variety of emphatic reiteration of the statement that wilfulness and wantonness are entirely, utterly, wholly and otherwise absolutely distinct from negligence. 45 C. J. 67I-674. A rather extensive effort to reconcile the cases has convinced the writer that the judiciary is protesting too much. See e. g. Peavey v. Peavey, 36 Ga. App. 202, 136 S. E. 96 (I926) (Guest Act) ; Adamowicz v. Newburyport Gas Co., 238 Mass. 244 , I30 N. E. 388 (I92I) ; cf. Young v. Worcester, 253 Mass. 48I, I49 N. E. 204 (1925). A similar amount of space is occupied by cases which alternately define gross negligence, deny its existence and identify it with or distinguish it from wantonness and wilfulness. See 45 C. J. 667-67r. A smaller, but substantial number is cited for the proposition that mere gross negligence does not preclude the defense of contributory negligence; while the qualification is made that this is not true where gross negligence and wilfulness or wantonness are synonymous. See 45 C. J. $982-983$. Consultation of the various digest systems reveals this situation even more clearly through the medium of more extensive quotation. Decisive proof of the mass of contradictions in this material would require, of course, analysis of the facts of the cases cited and demonstration that the distinctions drawn become meaningless in that process. This the writer has done in part by sampling; but for present purposes, only a few of the cases from a single jurisdiction need be cited, and factual analysis will be left to such readers as are curious to see the results in a theoretically coherent body of law. Michigan's supreme court has made the following statements, among others, on the points mentioned: gross negligence is negligence of an aggravated character, Buxton v. Ainsworth, I38 Mich. 532, I0I N. W. 817 (1904). It implies thoughtless disregard, Simon v. Detroit U. Ry., 196 Mich. 586, I62 N. W. IOI2 (I917). It imports wilfulness, Finnegan v. Michigan Central R. R., 127 Mich. ${ }^{15}, 86$ N. W. 395 (I90I). Also wantonness, Denman v. Johnston, 85 Mich. 387,48 N. W. 565 (I891). But, accurately speaking, negligence and wilfulness are incompatible terms, as are negligence and wantonness, Unnion Trust Co. v. Detroit U. Ry., 239 Mich. 97, 214 N. W. 166 (1927). And degrees of negligence are not recognized, Finkler v. Zimmer, 258 Mich. 336, 24I N. W. 851 (1932). Gross negligence, however, does not preclude the defense of contributory negligence, Gibbard v. Cursan, 225 Mich. 3I I, I96 N. W. 398 (I923). But where the term is used to mean wilful or wanton, it does, Patton y. Grand Trunk \& Ry., 236 Mich. I73, 210 N. W. 309 (1926); and the same is true where it is used to describe the conduct of a defendant who, it appcars, had a last clear chance, Denman v. Johnston, supra. 
striking a result. Here dissatisfaction is focused upon the boundary itself, not the definition of it, and there is a marked tendency to hurdle it and carry categorization from this point on down into the theoretically unitary area of negligence. Thus gross negligence is today much more respectable than formerly. ${ }^{80}$ Other terms indicating variations in degree of fault are progressively losing what once appeared to be sharp contours-a process greatly accelerated by their use in guest cases. ${ }^{61}$

It can be argued with reason that these trends are not for the better. Refinements of category still foster confusion, no matter how legitimate their object. At some point that confusion may become more obstructive to the attainment of justice than the complete absence of reform would have been. It seems probable that that point has already been reached in this instance. Progress towards a uniform comparative fault standard seems no more likely than does the effective clarification of the more rigid system of categorization.

A numerically less important application of the rule that contributory negligence is not a defense to actions not based on negligence is presented in the absolute liability cases. ${ }^{62} \mathrm{~A}$ hasty analysis might lead to the conclusion that this problem is essentially indistinguishable from those raised by the various gradations of fault greater than negligence. In fact, it is quite different. Absolute liability is simply a name applied to various liabilities which, in widely differing types of cases, are imposed without the necessity of finding negligence or any other type of fault on the part of the defendant. Some of the instances of its application are apparently the result of a feeling that the standards which negligence rules impose are not sufficient safeguards against the dangers of certain types of conduct. Typical of these are the dynamite cases. ${ }^{63}$ Others represent a middle point between ordinary negligence cases and those like workmen's compensation cases in which some social policy has dictated consideration of elements other than the relationship of the parties to the precise circumstances of the injury. Liability of principals for agents' torts can be classified here. ${ }^{64}$ Others still are

60. See note 59 supra.

6. See Note, Negligence-The Determination of Existence of Gross Negligence Making Automobile Host Liable to Non-Paying Guest (1937) 35 Mrct. L. REv. 804, for some account of the effects of the Massachusetts and Michigan acts. $C f$. Mole and Wilson, supra note $\mathrm{I}$ at $625-628$.

62. Lynch v. McNally, 73 N. Y. 347 (I878). See generally, HARPER, TorTs (I933) § I52; Harper, Liability Without Fault and Proximate Cause (1932) 30 MICH. L. REv IOO2..

63. For a list and analysis of ultra-hazardous activities so treated see, RestateMENT, TORTS (I938) $\$ \$ 519-523$.

64. This group of cases is not, of course, ordinarily classified among those imposing "absolute" liability. That liability is imposed without the necessity of finding actual fault on the part of the defendant, however, is a commonplace of agency law. This doctrine seems to be a step towards transferring to a group the loss which unavoidably follows carrying on business in a given way. That it constitutes a satisfactory method of solving the problem may be doubted. See note I6 supra for com- 
explainable only by an appeal to history, like trespassing animal cases, ${ }^{65}$ and, finally, some seem impossible to explain at all. Fletcher $v$. Rylands ${ }^{68}$ occupies this niche in the writer's mind. ${ }^{67}$

Analogy to the recklessness and wilfulness cases might be argued as a basis for refusing the defense in the first group, but with doubtful exactness. It is probably true that this category of liability is actually based on fault - a very high degree of fault verging on that characterized as intentionality. Thus it may be said that dynamite is so dangerous a substance that a prudent user must know he will be likely to inflict injury no matter how careful he is. ${ }^{68}$ It then is easy to say that he must recompense those injured so long as they do not make his task of protecting them unduly difficult. But it would seem to be an open question whether he must necessarily take added precautions to avoid the effects of substandard conduct on the part of his neighbors. ${ }^{69}$ And nothing in the doctrine tells us why the question has been decided as it has.

Explanation by an analogy to the rather questionable doctrine that even consent will not bar actions for injuries caused by conduct which is thought highly antisocial fails, because dynamiting is nothing like the types of conduct so treated but, on the contrary, is generally thought socially beneficial. ${ }^{70}$ A better explanation-if not justification-may be that contributory negligence is not an appealing doctrine at best and will not be applied where there is any pretext for avoiding it. This, of course, offers as great an opportunity for unfairness to the defendant as contributory negligence at its worst does for the plaintiff. Again,

ment on the availability of liability without fault as a remedy in situations where community interest demands some solution other than that afforded by the negligence concept.

65. See Restatement, Torts (I938) $\$ \$ 504,505$.

66. L. R. I Ex. 265 (I866).

67. But see Bohlen, The Rile in Rylonds v. Fletcher, (IgIr) 59 U. of PA. L. Rev. 298, 373, 423. Cf. HoLkES, op. cit. supra note I4 at II6-II7.

68. This seems to be the basis of the Restatement rule. Restatenrent, Torts (1938) \& 519.

6. See Restatement, Torts (I938) $\$ 524$, which precludes only plaintiffs whose negligence aids in the miscarriage of the activity and those with knowledge, not of its danger, but of the fact that it is about to miscarry. Possibly the explanation lies in the similarity of the dynamite cases to those in which liability is imposed upon possessors of dangerous animals. But in the latter cases, the utility of the enterprise is undoubtedly thought significant. $I d$. at $\S \S 506,507,509,518$. The possessor of an abnormally gentle bear is absolutely liable. The possessor of a normally dangerous bull is not. Comparison of the actual danger involved in the respective activities is not determinative of liability. It is the social utility of the enterprise which tips the balance. However irrelevant this factor might seem to the process of compensating the plaintiff (see note 16 supra), it is extremely difficult to understand why it has not been carried over into the blasting cases to the extent of allowing the defense of contributory negligence generally. (See note $7 \mathrm{r}$ infra.) It is possible that the rules applicable to participants and those coming into danger with notice are expanding to this point. Restatenrent, ToRTS (1938) §523.

70. This explanation would also be objectionable on the basis discussed at length above that if "anti-social" means anything broader than "likely to harm the plaintiff", adversary litigation is not the place to seek out and apply the remedy required by the relevant social policy. See note 16 supra. 
the result of failing to give open recognition to comparative fault is the cause of probable failure uniformly to achieve its ends. Even more true is this of the second category of absolute liability. One could be almost certain that plaintiffs would frequently be unduly favored from a comparative fault viewpoint if contributory negligence were no defense to the principal who responds for his agent's wrongs. But apparently because this category of liability has been kept distinct from others characterized as absolute, the defense is here allowed. The fatal results of classification are evident in the third category, however. That liability for trespassing animals is absolute is an historical relic in any case. That contributory negligence is no defense seems a pure anomaly, although a tenderness for landowners inherited from an earlier day in English law may aid in explaining it. Finally, a refusal to permit the defense in the Fletcher $v$. Rylands situation presents the hardest problem of all. If this refusal is settled law, ${ }^{71}$ nothing would seem to explain it other than the observation that since the reason for liability in such cases is unknown, its limits are equally obscure.

If the purely verbal logic of the proposition that contributory negligence is a defense only to actions based on negligence is disregarded, then, it is apparent that the refusal to permit it in the absolute liability cases is difficult of convincing explanation. Not a little of this difficulty arises from the absence of a satisfactory rationale for some of the types of absolute liability themselves. But even where the outline of that rationale may be discerned, it affords little justification for refusal to permit the defense, assuming that the defense itself is satisfactory and desirable within the scope attributed to it by traditional doctrine. If, as it is believed, there is in this tangle an observable trend towards comparative fault, it seems apparent that the necessity for working in the dark toward that end has here resulted in some overcompensation for the injustices plaintiffs have suffered at the hands of contributory negligence in other fields.

Problems similar to those raised by refusal of the defense in absolute liability cases may appear under the perplexed doctrine of nuisance. Where nuisance arises from negligence, it has properly been said that differentiation from other negligence cases would be logically insupportable. $^{72} \mathrm{But}$, in the so-called absolute nuisance cases, more doubt arises. ${ }^{73}$ Without entering into extended analysis here, ${ }^{74}$ it may

71. The extreme variations in what is usually regarded as a unitary rule may well result in distinctions on this point. The trespassing and dangerous animal cases need not be analogized. Indeed, analogy to the more limited liability of possessors of domestic animals not known to be abnormally dangerous seems equally available. Cf. HARPER, TORTS (I933) \& I 52 .

72. McFarlane v. Niagara Falls, 247 N. Y. 340,160 N. E. 39I (I928).

73. See cases collected in Note (I928) 57 A. L. R. 7.

74. See Notes (1935) 23 Calif. L. Rev. 427; (1934) 29 Ill. L. Rev. 372. 
be said that the complex mazes of absolute nuisance seem to include cases corresponding to each of the categories of absolute liability discussed above and also some where the position of the plaintiff is the determining circumstance, as in private nuisance situations. Any general statement that contributory negligence is not a defense to all of these types of absolute nuisance is probably too broad, ${ }^{75}$ But to say that the utmost confusion pervades the whole question of its applicability is certainly justified. And, as in the absolute liability categories, there is more than a suspicion that even-handed injustice is being done by a wholly capricious system of favoring, now an undeserving plaintiff and now a defendant no more worthy, by reason of the confusion which results from the refusal openly to compare their faults.

It is beyond the scope of this paper to attempt solutions for the problems of these tangential fields. It is quite possible that some of them would remain if the confusing factor of contributory negligence and the covert reactions against it were removed, Thus the absolute liability and nuisance categories might continue to be baffling in any event. But it is hard to doubt that solutions for all of these problems would be greatly simplified by clarification of the contributory negligence situation, and that some of them would entirely disappear,

Their genuine significance here, however, is that they point to the central difficulty of contributory negligence. Each has been used as an avenue of escape from the essential unfairness of that doctrine in its accepted form. Yet none of them has proved satisfactory for the purpose. By devious and uneven methods they have made an approach to comparative fault by attempting to avoid refusing recovery to a plaintiff whose conduct appears somehow less culpable than that of the defendant although not entirely blameless. At least three elements have combined to obscure and hamper this process. First is the failure sufficiently to limit the stated function of the negligence concept, a failure which, as has been pointed out above, has tended excessively to sanctify its present form and that of its attendant doctrines, To this underlying source of difficulty is added a second which arises largely from the first, the refusal to acknowledge the propriety of considering comparative fault at all, The extent to which this has led to unacknowledged evasions with accompanying difficulties of analysis and contradictory results has been suggested above. The final obstructive element, however, seldom appears on the surface at all, yet is, perhaps, the most important reason why no rational solution for any of the above problems has yet been reached or is even in prospect. The development of various fields of the common law toward unacknowledged ends by 
indirection is a process so familiar and so frequently successful that any criticism based merely on the proposition that such a process was going on and had not yet reached perfection could justifiably be disregarded. Thus the two obstructive elements already referred to could be dismissed with the statement that the uneven and obscure revision of the contributory negligence rules toward comparative fault is no sufficient cause for concern. Even where the process has reached an apparent impasse because of the very complexity of the methods by which it is carried on, as in the categorization of degrees of fault, the ultimate discovery of some satisfactory detour or short-cut might confidently be expected.

But the third and a fundamental objection remains. It is the fact that the end towards which this process tends is in itself unsatisfactory. The groupings toward comparative fault are an attempt to cure only the most obvious injustice of contributory negligence. At the maximum they can aspire only to the elimination of situations in which the plaintiff is less at fault than the defendant and still is denied recovery. Admitting the premise that one or the other must bear the whole loss, no more can be done. No one's sense of fairness would countenance permitting a plaintiff who was the more at fault to foist the entire loss onto the defendant. ${ }^{76}$

But why must that premise be admitted? So long as it stands, the attempted cure for the unfairness inherent in contributory negligence will be of necessity only a shade less bad than the disease. The only alternative to leaving the plaintiff uncompensated for an injury in which the defendant admittedly participated is to saddle the defendant with the entire cost of what the plaintiff helped him do. In the multitudes of cases where varying degrees of responsibility lie with each party, it is small wonder that the boundary between these two results is gerrymandered. That this situation should force judges into unacknowledged devices for striking a finer balance of comparative fault than is permitted by traditional doctrine is less surprising than their failure to recognize that refinements in the method of determining comparative fault are, when applied to impose the whole loss upon one party, simply more accurate methods of arriving at a wrong result. The tendency of juries, already noted, to find compromise verdicts despite all efforts to prevent them from doing so would seem to indicate that their perceptions are the less hampered by legal verbiage.

76. The real objection to the "Humanitarian Rule" is that it is subject to suspicion of doing exactly that. Its adoption is probably the reflection of a feeling that inadvertence in carrying on certain highly dangerous activities is worse than the failure on the part of the victim to guard against injury by them. But open expression of that feeling is precluded except in the absolute liability cases. The result is a subterfuge which satisfies no one. 


\section{III}

These observations are not novel. It has been pointed out elsewhere ${ }^{77}$ that the pull to escape the injustice to the plaintiff wrought by rigid application of contributory negligence rules results in injustice to the defendant; that while a delusion of fairness may be created by averaging out the results and finding that plaintiffs in general are favored about as often as defendants in general, there are in fact no plaintiffs or defendants in general, but only individual litigants each of whom is the recipient of unjust burden or undue favor in his own particular controversy. The homely observation that two wrongs do not make a right could find no better illustration.

The solution of the difficulty similarly lacks novelty. Some forms of loss distribution have existed very nearly as long as the problem itself. $^{78}$ Many different forms have been suggested or actually put into operation at varying times and places and for varying purposes. The most accurate of them may be rejected out of hand. Rigid logical analysis of causation and the full utilization of the findings of psychology and other sciences might suggest that the loss arising from a given accident should not be divided between two parties only but distributed over a wide range of individuals and even inanimate factors. But the mere prospect of attempting to allocate the expenses of Brown's injuries at the hands of Kendall in the course of the latter's efforts to end a dog fight among those responsible for the deficient training of the dogs, the dogs themselves, those upon whom a phychologist might place responsibility for the respective mental states of the parties, and low visibility -to mention only a few of the myriad possible factors-is sufficient to demonstrate the hopelessness of attempting any such distribution within the adversary system of litigation. ${ }^{79}$ Further, such a distribution would undoubtedly fail to satisfy current popular standards of fairness.

At the other extreme stands the arbitrary division of loss between the parties on some fixed basis. This has the merit of simplicity in administration; and giving a badly injured plaintiff who was only slightly negligent fifty per cent. of his loss; this is fifty per cent. better than nothing. But it may also be forty-nine per cent. short of a fair solution. ${ }^{80}$ Perfection cannot be expected of the admittedly rough and ready system we are examining. Half a loaf may be better than none. But such a method should not be adopted if a better is available.

77. Lowndes, note I2 supra at 708-709. See also, Gregory, Legislative Loss Distribution IN Negligence Actions (1936) 52.

78. A comprehensive analysis of these may be found in Mole and Wilson, note I supra at 604 .

79. Cf. Cowan, note 27 supra at 67 and Cowan, note Io supra at 539 .

so. Comparative negligence and loss cannot, of course, be expressed in exact percentages. But this method of relation offers a convenient form of illustrative shorthand. 
Between the two methods suggested stands the one which makes comparative fault a basis for reduction in the plaintiff's damages pro tanto. It has been said of this that "the task of apportioning damages according to the respective contributions of the plaintiff and defendant ... is an undertaking which . . . cannot be performed accurately by any human agency". ${ }^{81}$ With this one readily agrees. Equally valid is the statement by the same authority that "it seems impossible to evolve any formulæ which will produce even an approximately accurate apportionment in a large run of cases". ${ }^{82}$ Illustration of these difficulties seems superfluous. But are these objections sufficient to condemn the method altogether? Need we be sure of accuracy or acceptable formulæ before preferring this type of loss distribution to what we now have? The ideal method of determining the merits of the two methods would, of course, be an appeal to experience. This is unfortunately impossible. There is no way of knowing, in any positive sense, either how bad the results of present systems are nor how good are those obtained in experience with the proposed reform where it has been tried. As to the former, one must reason from the rather scattered and remote indicia noted above. The teaching of experience under the reformed system is encouraging, but almost wholly negative. $^{83}$ It can be said with confidence that no cataclysms have attended the application of various types of loss distribution. Juries have not failed to function at all under these rules, nor have judges been so unable to guide their functioning that the legal system has been hampered in its operation. Nor is popular reaction so unfavorable as to create any observable demand for their abandonment. ${ }^{84}$

Beyond these findings, the lack-and impossibility-of statistical information about the actual results of litigation under any system necessitates reliance on sheer a priori reasoning in dealing with the problem. The problem is: would application of comparative loss distribution reach results more closely approximating the popular conception of fairness or justice in individual litigations than does the present doctrine of contributory negligence together with all its satellite doctrines varied as they now are by the behavior of juries? What now governs these cases is the purported rule that a plaintiff who has been negligent in the slightest degree cannot recover from a defendant who is less than grossly negligent, who is not liable without fault or for absolute nuisance and who had no last clear chance. Varying that rule is a confused tangle of exceptions and overlapping rules-statutory

81. Lowndes, note i2 supra at 683 .

82. Id. at $683-684$. It is assumed that by "formulæ" this statement means specific criteria of comparison.

83. See Mole and Wilson, note I supra at $633-655$.

84. Ibid. 
and judge-made alike-which approach to greater or less degree the outlawed doctrine of comparative negligence, ${ }^{85}$ giving complete victory to one party or the other after a more refined analysis of responsibility. Finally, there is the hidden rebellion on the part of some juries in favor of the loss distribution system, working erratically and in unknown proportions toward what results we cannot say.

To such a system, if system it can be called, objections are legion. It is at best unjust, even if it achieves uniformly the result of comparative negligence. It almost certainly does not do even that very well. Within the interstices of its contradictions and confusions even greater injustices may be and probably are multiplied. It requires an everexpanding series of rules of law to restrain its own vagaries and those of juries who find in it no guide to intelligent judgment.

What is proposed is that juries be permitted to work out by the exercise of their understanding of the popular standards of fairness a distribution of loss between the two parties before them. The chief objection is that juries are not to be trusted so far. This may be broken down into two separate ideas. First a general distrust of juries which fosters a preference for leaving a large measure of control with the judge to be exercised by "rules of law"; and second, the belief that the problem is incapable of solution by anyone and hence not by a jury. The two should be dealt with separately.

There is undoubtedly much reason for distrust in juries. Their emotions frequently sway their judgment. And there is reason to suspect that they quite generally fail to understand and follow any but the simplest rules laid down for their guidance or any but relatively simple fact situations. Any reform in negligence law short of one supplanting juries by a body of broadly qualified experts must be viewed with this attribute in mind. From this point of view, the proposed system of distribution of loss seems not worse but better than what we have. At present, the function of rules of law in cases where negligence is alleged as to both parties is to lay down a series of barriers the sole purpose of which is to prevent the jury from doing what its natural instincts dictate. They must not compare the conduct of the parties for the purpose of fixing liability or determining its proportional incidence upon them. Instead they must listen attentively to descriptions of the state of law upon negligence, contributory negligence, and, in a growing number of cases, last clear chance, and find their way out

85. In Illinois, the pure comparative fault doctrine was followed for some years, forcing defendant to pay for the entire injury so long as his fault was greater than that of plaintiff. St. Louis, A. \& T. H. R. R. v. Todd. 36 III. 409 ( I865); Galena \& Chicago U. R. R. v. Jacobs. 20 Ill. 478 ( 1858$)$. With its disappearance in this state-see Calumet Iron \& Steel Co. v. Martin, II5 Ill. 358 (I885) -overt comparison of fault substantially disappeared. See for comment on this doctrine, CooleY, Torrs (4th ed. I932) $\$ 4 \$ 5$. 
of the resulting maze as best they can. Even assuming that the intricate legal doctrines thus presented to them are perfect instruments for the accurate allocation of liability, it seems evident that their very complexity is a fertile field for the growth of the very faults for which the jury is already condemned. If distrust of juries arises from their inability to follow close and intricate legal reasoning, the cure is not to be found in our present tendency to concoct increasingly complex limitations on their activity which, in the last analysis, they must understand and apply. Simplification of rules and utilization of the jury's natural predilections wherever possible is surely a more practical method of preventing the increase of uncontrolled vagaries in their conduct.

The second objection-that the task itself is impossible-seems no more persuasive. Of course it is impossible to allocate damages accurately between two negligent parties. The impossibility of laying down accurate and detailed rules for the performance of this impossible task is even more apparent. But these propositions seem to offer no basis for the supposition that worse results will be reached by permitting juries to attempt a fair and rational solution than by forcing upon them complicated rules the purpose of which is to coerce them into reaching one which is unfair and irrational.

It is submitted that better results can probably be obtained by entrusting to the good sense of juries-limited as it may be-the task of making as fair an apportionment as they can than by entrusting to the nonsense of the present rules of contributory negligence the task of seeing to it that no fair apportionment be permitted. The function of juries in our law is precisely the performance of the impossible in any event, $^{86}$ and this task seems to be an impossibility quite as much within their competence as others which they now perform. A certain amount of guidance would, of course, be required. It seems quite likely that such directions as are given the jury under the Wisconsin rule ${ }^{87}$ or the Ontario statute ${ }^{88}$ would be at least as effective both for guidance and as a basis for review as the enormously complex dissertations now require. Ultimately, it might be expected that degrees of negligence would be worked out, not as a result of rules imposed by appellate courts after discovery by a priori reasoning, but by the gradual process

86. See British Phosphates and Beef Extract Ltd. v. The United Alkali and Guano Simplex Ass'n, HERBERT, UNCOMMON LAW (I936) 209. No lawyer can seriously believe that juries actually discover the precise facts underlying any given controversy. It is a patent impossibility even in the simplest cases. Indeed, the very existence of "facts" as they are sought in negligence cases is highly doubtful. See FRANK, LAW AND THE MODERN MIND (1930) I70-185.

87. Wis. Laws, I93I, c. 242, WIs. Stat. \& 331.045. See 4 Wis. State Bar Ass'N Bull. 232-236; Mole and Wilson, note I supra at 651 .

88. Ontario Laws, I924, c. 32. Note that this act provides for arbitrary division of damages where comparison is impracticable. See for a discussion of decisions under this act, MacIntyre, note 30 supra at I24I-I25I. 
of experience and observation on the part of nisi prins judges who would be in direct contact with juries and the operation of the new doctrine upon large quantities of cases. This is the traditional method of developing standards described by Holmes. ${ }^{89}$ And if to evoke its efficient functioning the slate must be wiped clean of inconsistent precedent, it should be done. ${ }^{90}$ If it is not, the rigidity of the existing rules may soon be supplanted by the greater rigidity attendant upon statutory reform-an eventuality which is neither necessary nor desirable within the area of relatively isolated accidents as to which no clear social policy yet exists. The gradual evolution of judicial legislation here has its most obvious utility. It should be given the opportunity to function.

89. HoLMes, op. cit. stlpra note 14 at I2I-I29.

90. Id. at I25-126. ". . these considerations only lead to the conclusion that precedents should be overruled when they become inconsistent with present conditions. . ." Cf. Mr. Justice Stone, The Common Law in the United States (1936) 50 HARv. I. REV. 4, 7-I2. 